\title{
Effects of Day Relative to Parturition and Dietary Crude Protein on Rumen Fermentation in Prepartum Transition Cows
}

\author{
M. E. Dorshorst and R. R. Grummer ${ }^{1}$ \\ Department of Dairy Science, \\ University of Wisconsin, Madison, 53706
}

\begin{abstract}
Twelve Holstein cows and eight heifers were used in a randomized block design to examine changes in rumen fermentation and blood metabolites as animals fed diets containing 9.1 (low protein, LP) or $11.2 \%$ crude protein (moderate protein, MP) approached parturition. Animals were blocked by expected calving date and parity. Diets were isocaloric (1.58 Mcal/kg of dry matter), and the difference in dietary crude protein was achieved by the addition of urea. Diets were fed as total mixed rations for ad libitum intake. Dry matter intake decreased from $12.2 \mathrm{~kg} / \mathrm{d}$ on $\mathrm{d}-21$ to $9.1 \mathrm{~kg} / \mathrm{d}$ on $\mathrm{d}-1$ relative to parturition and was unaffected by dietary crude protein or parity. Rumen ammonia concentrations were higher for animals fed the MP diet compared with those fed the LP diet (1.8 vs. $3.7 \mathrm{mM}$ ). In situ neutral detergent fiber disappearance was not affected by dietary crude protein after $8 \mathrm{~h}$ of incubation, but it did decrease from $25.8 \%$ on $d-21$ to $23.3 \%$ on $d-1$. After 16,24 , and 48 $\mathrm{h}$ of incubation, neutral detergent fiber disappearance was greater for animals consuming MP than for animals consuming LP (30.6 vs. $34.4 \%, 37.0$ vs. $44.1 \%$, and 57.9 vs. $65.1 \%$, respectively). There was a parity $\times$ treatment interaction after $48 \mathrm{~h}$ of incubation. Fiber disappearance was 55.7 or $65.9 \%$ for heifers and 60.0 or $64.7 \%$ for cows fed LP or MP, respectively. The solids rate of passage was not affected by treatment, parity, or day relative to parturition. Concentrations of plasma nonesterified fatty acid (NEFA) increased from 218 $\mu \mathrm{Eq} / \mathrm{L}$ on $\mathrm{d}-21$ to $619 \mu \mathrm{Eq} / \mathrm{L}$ on $\mathrm{d}-1$. There was an interaction between day relative to parturition and parity on NEFA concentrations. Heifers had plasma NEFA concentrations of 272 and $772 \mu \mathrm{Eq} / \mathrm{L}$ on $\mathrm{d}-21$ and -1 , respectively. Cows had NEFA concentrations of 164 and $467 \mu \mathrm{Eq} / \mathrm{L}$ on $\mathrm{d}-21$ and -1 , respectively. Plasma glucose
\end{abstract}

Received December 27, 2001.

Accepted March 3, 2002.

Corresponding author: R. R. Grummer; e-mail: rgrummer@ facstaff.wisc.edu.

${ }^{1}$ Partially funded by: Church and Dwight, Diamond V, Degussa, Kemin Industries, Land O' Lakes/Farmland Feed, Archer Daniels Midland, Pioneer Hybrids and ZinPro. concentrations were affected by parity ( 65.8 and 58.8 $\mathrm{mg} / \mathrm{dl}$ for heifers and cows). Plasma urea, NEFA, betahydroxybutyrate, and glucose concentrations were not affected by dietary treatment. In conclusion, heifers tended to have higher plasma concentrations of NEFA and glucose, but did not have elevated concentrations of beta-hydroxybutyrate. Rumen fermentation was relatively unaffected by day relative to parturition, but feeding less than $11 \%$ crude protein to prefresh transition cows may limit ruminal fiber degradation.

(Key words: prepartum transition cow, fiber degradation, protein)

Abbreviation key: $\mathbf{L P}=$ low protein, $\mathbf{M P}=$ moderate protein.

\section{INTRODUCTION}

The prepartum transition period represents a unique set of physiological and nutritional challenges for dairy cattle. Dry matter intake decreases significantly as cows approach parturition (Hayirli et al., 1998). In addition, there are metabolic and hormonal changes associated with parturition and lactogenesis that may induce disorders when cows transition from a nonlactating to a lactating state (Chew et al., 1979; Kunz et al., 1985; Bertics et al., 1992).

There has been extensive research in transition cow nutrition to identify ways to minimize complications that can occur during or shortly after the transition period. However, minimal research has been conducted to monitor changes that occur in the rumen environment as DMI decreases and parturition approaches. Stanley et al. (1993) used beef cows to measure changes in rumen environment and fiber degradation during the transition period. Measurements of DMI, OM fermentation, and fermentation end products were made on $\mathrm{d}-61,-48,-34,-20$, and -6 relative to parturition. Dry matter intake increased from 8.8 to $11.1 \mathrm{~kg} / \mathrm{d}$ as days dry increased. Rumen $\mathrm{pH}$, VFA concentration, and DM digestibility were not affected during the dry period. Because there was no intake depression observed in this study, the results may not reflect what typically occurs in prepartum transition dairy cattle. 
Several studies have monitored changes in rumen function and fiber degradation that occurs when voluntarily restricting feed below ad libitum intake. Hart and Glimp (1991) utilized sheep on a primarily concentrate diet and restricted feed to 92.5 and $85.0 \%$ of ad libitum intake. They observed no effects on total tract DM digestibility or rumen $\mathrm{pH}$, ammonia, or VFA concentration and proportions. An increase in total tract ADF digestibility was observed as feed intake was restricted. Robinson et al. (1985) found that as Holstein cows were feed-restricted from 17.4 to $6.0 \mathrm{~kg}$ of $\mathrm{OM}$ per day, ruminal digestibility of $\mathrm{OM}, \mathrm{NDF}$, and $\mathrm{ADF}$ increased. Potential changes in rumen function or fiber degradation associated with involuntary reductions in feed intake have not been examined in prepartum transition dairy cattle.

The NRC (2001) recommends that diets fed to dry cows contain no less than $12 \% \mathrm{CP}$. In all but the final days of gestation, feeding diets with $12 \% \mathrm{CP}$ should provide more than sufficient metabolizable protein to meet requirements for maintenance and pregnancy in a mature cow. The NRC (2001) suggests that feeding diets with $12 \%$ CP may be necessary to maximize OM fermentation in the rumen. Increasing CP from 4.9 to $11.7 \%$ in diets fed to beef steers consuming low protein forage resulted in a linear increase in total tract fiber digestion (Olsen et al., 1999). There was also a linear increase in rumen ammonia and total VFA concentration. Adding 4\% urea to diets containing oat straw and molasses caused an increase in in situ OM disappearance of various forages incubated in the rumen (Dixon, 1999). Studies examining dietary CP effects on fiber degradation in prepartum transition dairy cows or heifers are not available. Maximizing fiber degradation in these animals is important because they are often in negative energy balance (Grummer, 1995).

The objective of this study was to measure changes in rumen environment and fiber degradation as cows and heifers approach parturition. In addition, we examined the effects of two dietary CP concentrations on rumen fermentation and plasma metabolites that may be affected by changes in fermentation.

\section{MATERIALS AND METHODS}

The University of Wisconsin-Madison College of Agriculture and Life Sciences Institutional Animal Care Committee approved all procedures involving animals used in this study. Twelve Holstein cows and eight nulliparous heifers were ruminally cannulated and utilized in a randomized block design with two treatments. Animals were blocked according to parity (heifers vs. cows) and expected calving date. Treatments were diets with $9.1 \%$ (low protein; LP) or $11.2 \% \mathrm{CP}$ (moderate
Table 1. Composition of diets.

\begin{tabular}{|c|c|c|}
\hline & $\mathrm{LP}^{1}$ & $\mathrm{MP}^{1}$ \\
\hline & $\longrightarrow$ & \\
\hline \multicolumn{3}{|l|}{ Ingredient composition } \\
\hline Corn silage & 63.6 & 63.6 \\
\hline Alfalfa silage & 17.0 & 17.0 \\
\hline Chopped straw & 5.0 & 4.2 \\
\hline Cracked corn & 13.4 & 13.4 \\
\hline Urea & $\ldots$ & 0.8 \\
\hline Trace mineralized salt & 0.5 & 0.5 \\
\hline Vitamins $^{2}$ & 0.2 & 0.2 \\
\hline Magnesium sulfate & 0.3 & 0.3 \\
\hline \multicolumn{3}{|l|}{ Nutrient composition } \\
\hline DM, \% (as-fed basis) & 46.0 & 45.7 \\
\hline $\mathrm{CP}$ & 9.1 & 11.2 \\
\hline $\mathrm{RDP}^{3}$ & 6.2 & 8.3 \\
\hline $\mathrm{RUP}^{3}$ & 2.9 & 2.9 \\
\hline $\mathrm{EE}^{3}$ & 3.0 & 3.0 \\
\hline $\mathrm{NDF}$ & 34.3 & 33.8 \\
\hline $\mathrm{NFC}^{3}$ & 49.2 & 47.7 \\
\hline $\mathrm{NE}_{\mathrm{L}}^{3}, \mathrm{Mcal} / \mathrm{kg}$ of $\mathrm{DM}$ & 1.58 & 1.58 \\
\hline \multicolumn{3}{|c|}{${ }^{1} \mathrm{LP}=$ Low protein $; \mathrm{MP}=$ moderate protein.} \\
\hline
\end{tabular}

protein; MP). To increase dietary CP, a portion of straw was replaced with urea (Table 1). Mean BW $( \pm$ SD) of animals assigned to the LP and MP were $743( \pm 100)$ and $721( \pm 105.5)$, respectively.

Animals began on trial at $\mathrm{d}-35$ relative to expected parturition. From d -35 until d -28 all animals received LP. On $d-28$, one-half of the cows and heifers were switched from LP to MP. Diets were fed as a TMR three times daily at 0700,1500 , and $2300 \mathrm{~h}$, allowing for $10 \%$ feed refusal. The DMI was measured daily. Samples of TMR and orts were collected once per week. Orts were composited within cow, and TMR samples were composited within treatment. Body weights were measured before the $0700 \mathrm{~h}$ feeding on $\mathrm{d}-21$ and -20 relative to expected parturition.

Samples of rumen fluid were obtained immediately before the $0700 \mathrm{~h}$ feeding $(0 \mathrm{~h})$ and $4 \mathrm{~h}$ after feeding on $\mathrm{d}-21,-14$, and -7 relative to the expected calving date and every other day thereafter until calving. Rumen $\mathrm{pH}$ was determined immediately after sampling, and a 1-ml aliquot of rumen fluid was acidified with $0.02 \mathrm{ml}$ of $50 \%$ (wt/vol) $\mathrm{H}_{2} \mathrm{SO}_{4}$ and frozen $\left(-20^{\circ} \mathrm{C}\right)$ until VFA analysis by GLC (Erwin et al., 1961; Technical bulletin \#856A; Supelco, Inc., Bellfonte, PA). A second 1-ml aliquot of rumen fluid was acidified with $0.02 \mathrm{ml}$ of $50 \%$ (wt/vol) TCA and frozen $\left(-20^{\circ} \mathrm{C}\right)$ until ammonia analysis (Chaney and Marbach, 1962).

Feed ingredients, TMR, and orts were dried in a forced-air oven at $55^{\circ} \mathrm{C}$ for $72 \mathrm{~h}$ for determination of DM. Feed ingredients were ground using a Wiley mill 
(2-mm screen; Arthur H. Thomas, Philadelphia, PA). Feed ingredients were analyzed for CP (AOAC, 1990) and NDF using $\alpha$-amylase and sodium sulfite (Mertens, 1999). Diet $\mathrm{NE}_{\mathrm{L}}$ was calculated based on NRC (2001) assuming $12 \mathrm{~kg}$ of DMI per day.

Gelatin capsules containing wheat middlings and 1.0 $\mathrm{g}$ of ytterbium $(\mathrm{Yb})$, lanthanum $(\mathrm{La})$, or cerium $(\mathrm{Ce})$ were administered to six cows and four heifers at 0700 $\mathrm{h}$ on selected days. Ytterbium was administered on $\mathrm{d}$ $-21,-14$, and -7 relative to expected calving date. Beginning on $\mathrm{d}-7$, markers were administered every other day in a rotation so that no less than $6 \mathrm{~d}$ elapsed between dosing with the same marker. Fecal grab samples were taken every $8 \mathrm{~h}$ starting at the time of dosing and continuing for $96 \mathrm{~h}$. Fecal samples were dried in a $55^{\circ} \mathrm{C}$ oven for $72 \mathrm{~h}$, ground ( $2 \mathrm{~mm}$ ), dry ashed (Combs and Satter, 1992), and $\mathrm{Yb}, \mathrm{La}$, and Ce concentrations were determined by inductively coupled plasma spectroscopy (Thermo Jarrell Ash Corp., Franklin, MA).

A dried, ground (2-mm screen), 5-g sample of the forage portion of the diet was placed into Dacron bags $(9 \times 15 \mathrm{~cm}$ and $52 \mu$ pore size; Blumgart, Inc., New York, NY) and incubated in situ on $\mathrm{d}-21,-14$, and -7 , and then every other day until parturition. Duplicate Dacron bags were incubated in the rumen for $0,8,16$, 24 , and $48 \mathrm{~h}$. Placement of the bags into the rumen was staggered so that bags could be removed all at once. Bags were moistened in warm water before being incubated in the rumen and were held in the rumen by a laundry bag containing a 500-g weight that was attached to the rumen cannula by a $45-\mathrm{cm}$ cord. Upon removal from the rumen, bags were immediately soaked in cold water and then transferred to a washing machine for rinsing (Cherney, et al., 1990). Empty bags and bags containing residue were dried at $55^{\circ} \mathrm{C}$ for at least $72 \mathrm{~h}$ for DM analysis. Residue NDF was determined using $\alpha$-amylase and sodium sulfite (Mertens, 1999).

Blood was sampled from a coccygeal vessel just before the $0700 \mathrm{~h}$ feeding on $\mathrm{d}-21,-14$, and -7 prior to expected calving and every other day thereafter. Blood was centrifuged at $900 \times g$ for $15 \mathrm{~min}$, and the plasma was removed and stored frozen at $-20^{\circ} \mathrm{C}$ until anlaysis. Plasma samples were analyzed for glucose (Raabo and Terkildsen, 1960; Sigma Glucose Kit 510, Sigma Diagnostics, St. Louis, MO), NEFA (NEFA Kit C, Wako Chemicals USA, Richmond, VA) as modified by Johnson and Peters (1993), urea (Crocker, 1967; Sigma BUN Kit 535, Sigma Diagnostics, St. Louis, MO), and BHBA (Williamson et al., 1962; Sigma Kit $\beta$-HBA 310-A, Sigma Diagnostics, St. Louis, MO).

Data were analyzed using the MIXED procedure of SAS (SAS, 1998). The following model was used for statistical analysis of repeated measurements over days.

$$
\begin{gathered}
\mathrm{Y}_{\text {hijklm }}=\mu+\mathrm{A}_{\mathrm{i}}+\mathrm{D}_{\mathrm{k}}+\mathrm{T}_{1}+\mathrm{P}_{\mathrm{m}}+\mathrm{V}_{\mathrm{j}(\mathrm{m})}+\mathrm{S}_{\mathrm{h}(\mathrm{jlm})}+\mathrm{DT}_{(\mathrm{kl})} \\
+\mathrm{DP}_{(\mathrm{km})}+\mathrm{TP}_{(\mathrm{lm})}+\mathrm{E}_{\mathrm{hijklm}}
\end{gathered}
$$

$$
\begin{aligned}
\mathrm{Y}_{\mathrm{iklmn}} & =\text { dependent variable; } \\
\mu & =\text { overall mean; } \\
\mathrm{A}_{\mathrm{i}} & =\text { effect of time } \mathrm{i} \text { within day; } \\
\mathrm{D}_{\mathrm{k}} & =\text { effect of day } \mathrm{k} ; \\
\mathrm{T}_{\mathrm{l}} & =\text { effect of treatment } \mathrm{l} ; \\
\mathrm{P}_{\mathrm{m}} & =\text { effect of parity } \mathrm{m} ; \\
\mathrm{V}_{\mathrm{j}(\mathrm{m})} & =\text { effect of block } \mathrm{j}\left(\mathrm{P}_{\mathrm{m}}\right) ; \\
\mathrm{S}_{\mathrm{h}(\mathrm{jl})} & =\text { effect of cow } \mathrm{h}\left(\mathrm{P}_{\mathrm{m}} \times \mathrm{T}_{\mathrm{l}} \times \mathrm{B}_{\mathrm{j}}\right) ; \\
\mathrm{DT}_{(\mathrm{kl})}= & \text { interaction between day } \mathrm{k} \text { and treatment } \\
& \mathrm{l} ; \\
\mathrm{DP}_{(\mathrm{km})}= & \text { interaction between day } \mathrm{k} \text { and parity } \mathrm{m} ; \\
\mathrm{TP}_{(\mathrm{lm})}= & \text { interaction between treatment l and par- } \\
& \text { ity } \mathrm{m} ; \\
\mathrm{E}_{\mathrm{hijklm}}= & \text { error. }
\end{aligned}
$$

All terms were considered fixed except $V_{j(m)}, S_{h(j l m)}$, and $\mathrm{E}_{\mathrm{hijk}}$, which were considered random. Terms were removed from the model in a backwards stepwise elimination manner if $P>0.25$. Terms were considered significant if $P<0.05$. All terms that were dropped from the model were pooled in the residual standard error term. Time $\left(\mathrm{A}_{\mathrm{i}}\right)$ was used only in the model for statistical analysis of rumen $\mathrm{pH}, \mathrm{VFA}$, and ammonia, where a measurement was made prior to feeding and $4 \mathrm{~h}$ after feeding. Since the MIXED does not calculate a pooled SEM, weighted averages of SEM across days before parturition are reported.

All data were adjusted to day of actual calving. To accumulate enough data points within a given period of time and facilitate statistical analysis, measurements for $\mathrm{d} 0$ and $-1, \mathrm{~d}-2$ and $-3, \mathrm{~d}-4$ and $-5, \mathrm{~d}-6$ and $-7, \mathrm{~d}-10$ to -17 , or $\mathrm{d}-18$ to -25 were grouped. These groups of days were designated as $d-1,-3,-5$, $-7,-14$, and -21 .

Rate of passage was calculated by regression of fecal marker concentration onto time of collection using data points following peak fecal marker concentration. The regressed value was then considered the rate of passage on the day the marker was administered.

There were insufficient time points for in situ NDF disappearance to be described as a rate. Therefore, measurements within each time point $(8,16,24$, and $48 \mathrm{~h})$ were analyzed seperately using the previously described model. Day refers to the day bags to be incubated for $48 \mathrm{~h}$ were placed into the rumen. 
Table 2. Effects of day relative to calving, dietary $\mathrm{CP}$ or parity on DMI, rumen $\mathrm{pH}$, and rumen ammonia concentration.

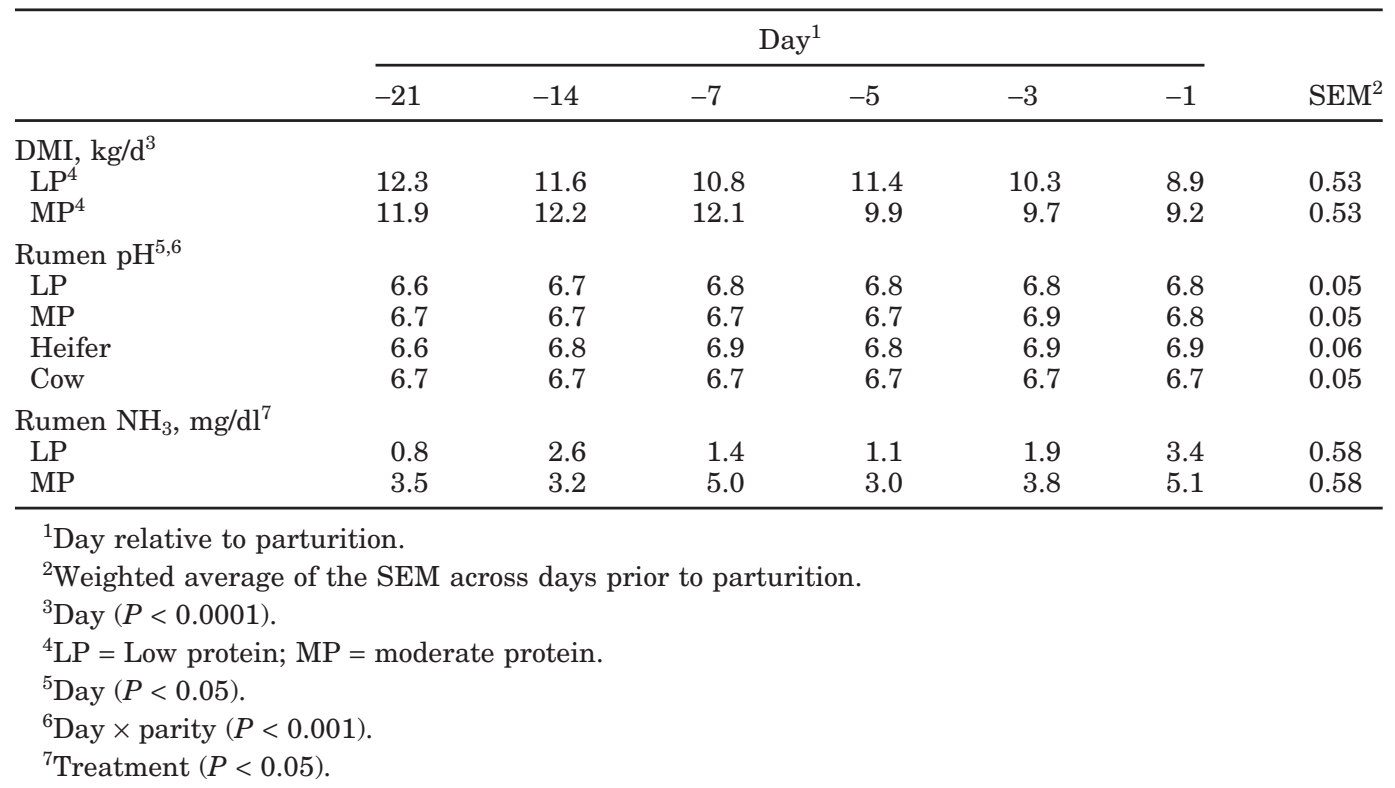

\section{RESULTS AND DISCUSSION}

The LP and MP diets (Table 1) were originally formulated to contain 10 or $12 \% \mathrm{CP}$ on a DM basis. Due to unexpected changes in forage $\mathrm{CP}$, diets were lower in $\mathrm{CP}$ concentration than originally planned (Table 1); however, approximately a two percentage unit difference in dietary CP was maintained between treatments.

Increasing the concentration of $\mathrm{CP}$ as RDP had no effect on DMI throughout the prepartum period. In a summary of studies, changing $\mathrm{CP}$ has had little or no impact on prepartum DMI (Grummer and Hayirli, 2001). Dry matter intake decreased as cows approached calving $(P<0.0001$; Table 2$)$. In contrast to studies summarized by Grummer and Hayirli (2001), there was no significant difference in DMI between heifers and cows.

Rumen $\mathrm{pH}$ decreased from 6.85 at $0 \mathrm{~h}$ to 6.64 at $4 \mathrm{~h}$ postfeeding $(P<0.0001)$. Rumen $\mathrm{pH}$ increased $(P<0.05)$ as animals approached parturition (Table 2). These changes in rumen $\mathrm{pH}$ were statistically significant but very small (less then $0.2 \mathrm{pH}$ units). Organic matter fermentation usually is not affected adversely until $\mathrm{pH}$ declines below 6.2 (Grant and Mertens, 1992; Grant and Weidner, 1992). There was also an interaction of day and parity $(P<0.001)$; $\mathrm{pH}$ in cows did not change with day relative to calving, and $\mathrm{pH}$ in heifers increased from 6.6 to 6.9 during the final 3 wk of gestation.

Rumen ammonia concentrations were greater for cows fed MP compared with cows fed LP $(P<0.05$; Table 2). This transient increase was expected, due to the presence of urea in the MP diet. The concentration of rumen ammonia was not different at $0 \mathrm{~h}$ and $4 \mathrm{~h}$ postfeeding (data not shown). Day relative to parturition did not have any effect on rumen ammonia concentrations. Even though feeding MP increased the concentrations of rumen ammonia, concentrations were low for both treatments. Satter and Slyter (1974) stated that rumen bacterial growth could be limited when rumen ammonia nitrogen concentrations are $\leq 5 \mathrm{mg} / \mathrm{dl}$. Rumen ammonia concentrations for cows fed LP were often below this; therefore, microbial growth may not have been optimized. The NRC (2001) model predicts that both the LP and MP diets would be limiting in RDP, especially the LP diet.

Rumen VFA concentration increased from 0 to $4 \mathrm{~h}$ postfeeding ( 80.6 vs. $90.9 \mathrm{~m} M ; P<0.0001$ ). The composition of rumen VFA changed from 0 to $4 \mathrm{~h}$ after feeding. Acetate decreased from 65.4 to $64.5 \%(P<0.05)$, and propionate increased from 17.4 to $18.4 \%$ of the total rumen VFA $(P<0.0005)$. Butyrate as a proportion of rumen VFA was not changed by time relative to feeding $(12.2 \% ; P>0.05)$. Concentration of total VFA did not change as animals approached parturition and was unaffected by CP level (data not shown). Animals fed LP had lower proportions of butyrate than animals fed MP $(P<0.01$; Table 3). Sakata and Tamate (1978) indicated that increased butyrate concentration in the rumen stimulated papillae growth. Increased rumen epithelial surface area has been associated with increased absorption of rumen VFA as well as chloride and sodium ions (Sehested et al., 2000). 
Table 3. Effects of day relative to parturition and dietary CP on rumen VFA composition.

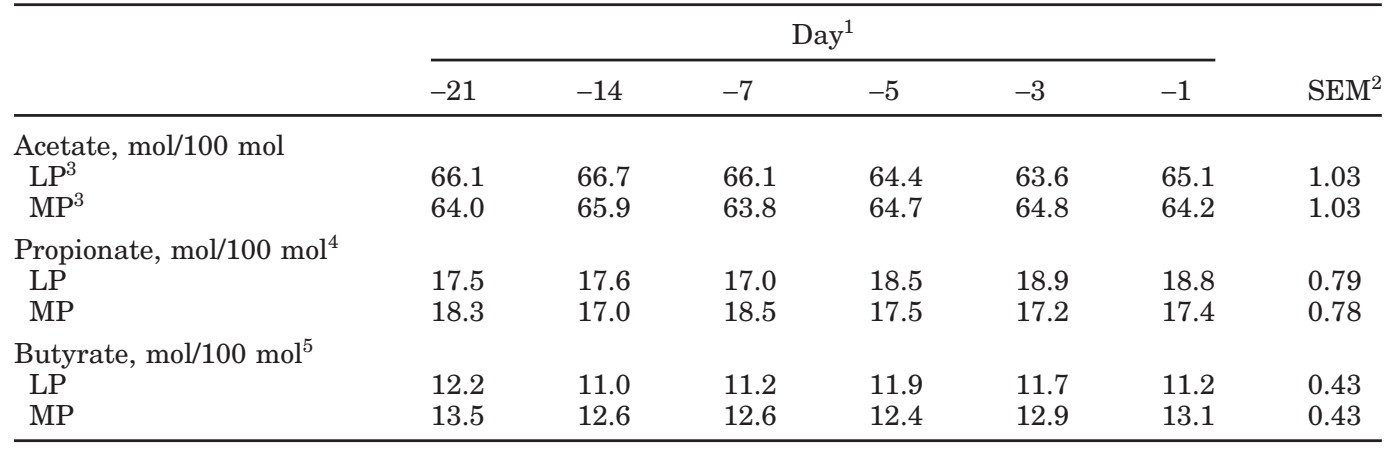

${ }^{1}$ Day relative to parturition.

${ }^{2}$ Weighted average of the SEM across days prior to parturition.

${ }^{3} \mathrm{LP}=$ Low protein; $\mathrm{MP}=$ moderate protein.

${ }^{4}$ Day $\times$ treatment $(P<0.05)$.

${ }^{5}$ Treatment $(P<0.01)$.

In situ rumen NDF disappearance was used to monitor changes in fiber utilization due to dietary $\mathrm{CP}$ and day relative to parturition. The in situ technique provides a reliable prediction of rumen digestibility for feedstuffs fed to dairy cattle (Arieli et al., 1998). Neutral detergent fiber disappearance at $8 \mathrm{~h}$ of incubation decreased $(P<0.0001)$ as animals approached parturition (Figure 1), but NDF disappearance at $16 \mathrm{~h}$ was not affected by day relative to parturition. Crude protein level did not affect NDF disappearance at $8 \mathrm{~h}$ of incubation (Figure 1), but NDF disappearance increased at $16 \mathrm{~h}(P<0.05$; Figure 2$)$ in animals fed MP compared with animals fed LP. The effect of CP on NDF disappearance continued and was magnified at $24 \mathrm{~h}(P<$ 0.001 ; Figure 3$)$ and $48 \mathrm{~h}(P<0.0001$; Figure 4$)$ of incubation. The decrease in fiber disappearance at $8 \mathrm{~h}$

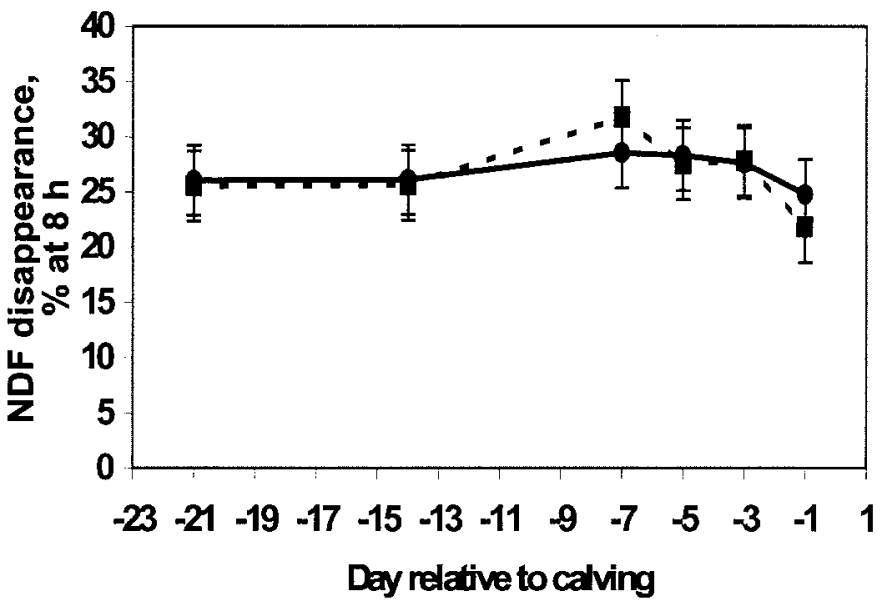

Figure 1. Effect of dietary CP concentration $(9.1 \%$ CP, $\mathbf{\square} ; 1.2 \%$ $\mathrm{CP}, \bullet)$ on NDF disappearance from Dacron bags after $8 \mathrm{~h}$ of incubation. Overall effect of day was significant $(P<0.0001)$. of incubation as parturition approached reappeared as a trend $(P<0.10$; Figure 3$)$ at $24 \mathrm{~h}$ of incubation but not at $48 \mathrm{~h}$ of incubation. No significant interactions with parity were observed after 8,16 , or $24 \mathrm{~h}$ of incubation, but there was a significant interaction of parity and treatment $(P<0.05)$ after $48 \mathrm{~h}$ of incubation. Heifers had lower levels of NDF disappearance than cows (55.7 vs. $60.0 \%$ ) when fed LP, but slightly more NDF disappearance when fed MP (65.9 vs. 64.7\%). This indicates heifers might benefit more than cows from increased CP as RDP. However, most fiber probably resides in the rumen for less than $48 \mathrm{~h}$ (Bal, 1999).

Except for research by Stanley et al. (1993), we know of no other information available regarding changes in fiber degradation during the dry period. Stanley et al. (1993) did not observe differences in in situ fiber disap-

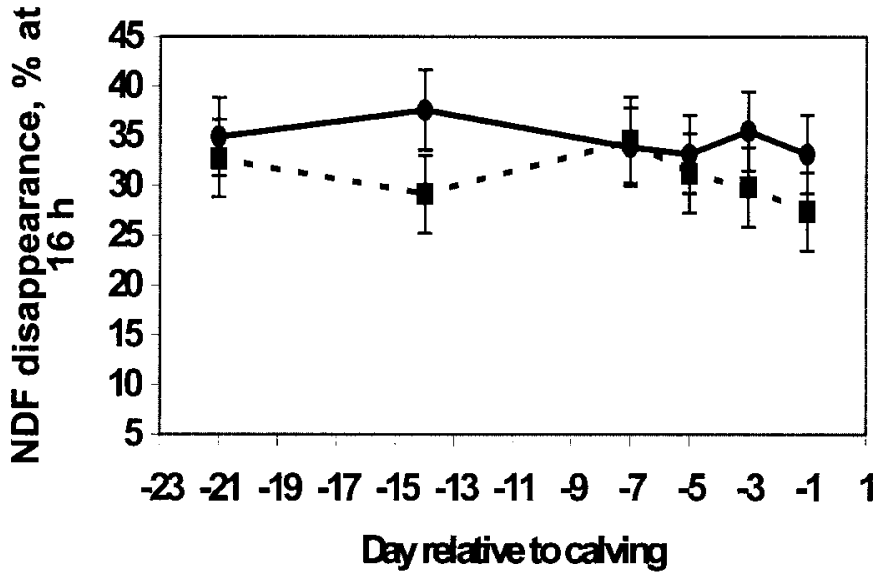

Figure 2. Effect of dietary CP concentration (9.1\% CP, $\mathbf{\square} ; 11.2 \%$ $\mathrm{CP}, \mathbf{0})$ on NDF disappearance from Dacron bags after $16 \mathrm{~h}$ of incubation. Effect of treatment was significant $(P<0.05)$. 


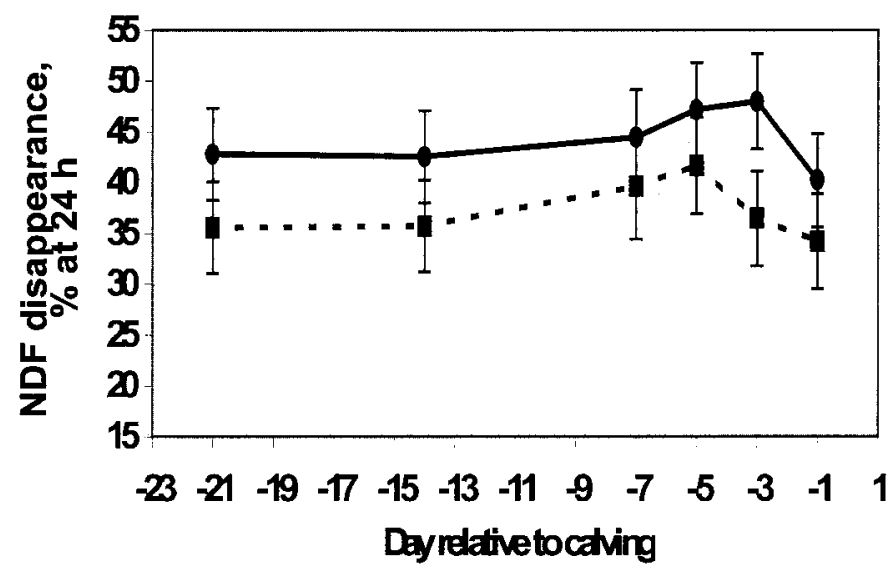

Figure 3. Effect of dietary CP concentration $(9.1 \% \mathrm{CP}, \mathbf{\square} ; 11.2 \%$ $\mathrm{CP}, 0$ ) on NDF disappearance from Dacron bags after $24 \mathrm{~h}$ of incubation. Effect of treatment was significant $(P<0.001)$. Overall effect of day relative to parturition tended to be significant $(P<0.10)$.

pearance at various times during the dry period. However, his study used beef cows that did not experience a decline in feed intake. Stanley et al. (1993) made measurements at more widely spaced intervals $(-61$, $-48,-34,-20$, and $-6 \mathrm{~d}$ ) before parturition. These differences could account for the different responses when comparing our results to those of Stanley et al. (1993).

It has been reported that feeding greater concentrations of RDP may increase in situ fiber and OM digestion (Dixon, 1999; Olsen et al., 1999). Dixon (1999) used four steers in a crossover design and fed diets containing approximately $7 \% \mathrm{CP}$ or $14 \% \mathrm{CP}$; the difference in $\mathrm{CP}$ was achieved with supplemental urea. There was increased in situ fiber disappearance for roughage sources when steers were fed the $14 \% \mathrm{CP}$ diet. Olsen

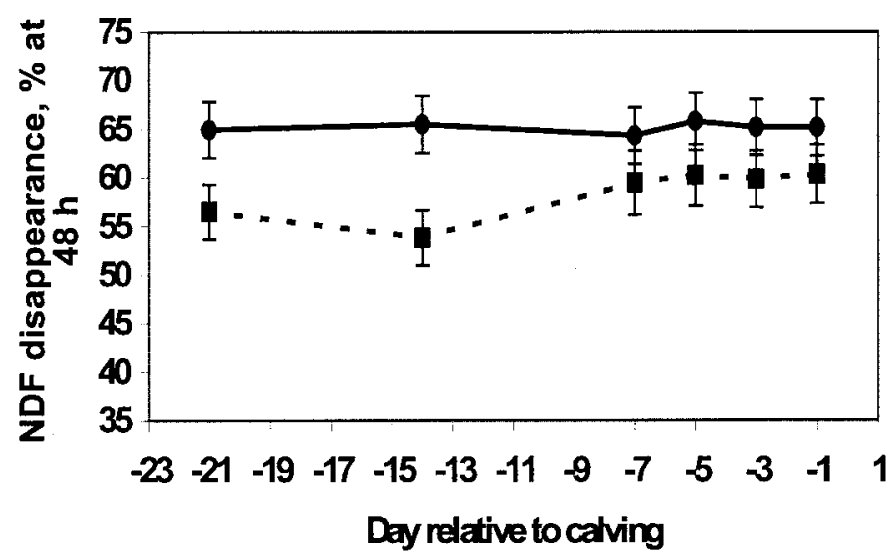

Figure 4. Effect of dietary CP concentration (9.1\% CP, $\mathbf{\square} ; 11.2 \%$ $\mathrm{CP}, 0$ ) on NDF disappearance from Dacron bags after $48 \mathrm{~h}$ of incubation. Effect of treatment was significant $(P<0.0001)$. et al. (1999) fed steers a basal prairie hay diet $(4.9 \%$ $\mathrm{CP})$ to determine whether ruminal infusion of $\mathrm{CP}$ affected fiber degradation in situ. The difference in dietary $\mathrm{CP}$ was achieved through daily infusion of sodium caseinate into the rumen at the rate of $0.0,0.03,0.06$, 0.09 , or $0.12 \%$ of initial BW. Assuming no changes in DMI or BW, this would equate to increasing dietary CP $0.0,1.7,3.4,5.1$, or 6.8 percentage units. As CP level increased, forage DM and OM degradation in situ increased. Rumen ammonia and total VFA concentrations increased as well. Increasing dietary CP from 11.6 to $15 \%$ using urea increased total tract crude fiber digestibility from 54.3 to $60.6 \%$ in dairy cows at 2 to $3 \mathrm{wk}$ prepartum (Doreau et al., 1990). Our results agree with those from other models and suggest that feeding a diet with less then $11.2 \%$ CP may inhibit fiber disappearance. Insufficient ruminal ammonia concentration may partially account for this effect.

The solids rate of passage, measured in 10 animals, was not affected by treatment $(\mathrm{LP}=5.69 \% / \mathrm{h}, \mathrm{MP}=$ $5.62 \% / \mathrm{h}, \mathrm{SEM}=0.59$ ). There was also no change in the solids rate of passage due to day relative to calving. Mean ( \pm SEM) solids rate of passage $(\% / \mathrm{h})$ on $\mathrm{d}-21$, $-14,-7,-5$, and -3 were $6.03( \pm 0.58), 6.08( \pm 0.61), 4.89$ $( \pm 0.68), 5.62( \pm 0.58)$, and $5.66( \pm 0.58)$, respectively. Because of the likelihood of cows not being in steady-state conditions and potential for slight differences in marker behavior and recovery, these measurements were made to obtain a crude estimation of changes in rate of passage. However, the relative consistency of the measurements across time indicates that cows were in steady state and marker differences were minimal, or any bias associated with these factors were nearly offset by changes in rate of passage. The lack of change in passage rate is unexpected given the depression in feed intake that occurs as cows approach parturition. Surprisingly, Barton (1981) observed an increase in the rate of passage in two Holstein cows at calving compared to $1 \mathrm{wk}$ before or after calving. Feed intakes were $11.0,9.2$, and $11.2 \mathrm{~kg} / \mathrm{d}$ at $7 \mathrm{~d}$ before calving, calving, and $7 \mathrm{~d}$ after calving, respectively. The solids rates of passage reported in our study were higher than previously reported for prepartum beef cows $(3.9 \% / \mathrm{h}$; Hanks, et al., 1993).

Fiber digestion in the rumen is a function of both the rate of degradation as well as retention time within the rumen. Because rate of passage was not affected by treatment, differences in in situ NDF disappearance may reflect NDF degradation in the rumen. There were insufficient time points to calculate rates of NDF disappearance from the in situ measurements. However, mean retention time of solids in the rumen for our diets was $17.5 \mathrm{~h}$. If we assume that fiber retention time was similar to or longer than the solids retention time, then 
Table 4. Effects of day relative to parturition and CP concentration on plasma metabolites.

\begin{tabular}{|c|c|c|c|c|c|c|c|}
\hline & \multicolumn{6}{|c|}{ Day $^{1}$} & \multirow[b]{2}{*}{$\mathrm{SEM}^{2}$} \\
\hline & -21 & -14 & -7 & -5 & -3 & -1 & \\
\hline \multicolumn{8}{|c|}{ Urea, mg/dl ${ }^{3}$} \\
\hline $\mathrm{LP}^{4}$ & 25.5 & 23.5 & 18.8 & 18.2 & 14.7 & 17.5 & 1.76 \\
\hline $\mathrm{MP}^{4}$ & 23.4 & 22.8 & 22.7 & 18.2 & 19.7 & 20.1 & 1.76 \\
\hline \multicolumn{8}{|c|}{$\mathrm{BHBA}, \mathrm{mg} / \mathrm{dl}^{5}$} \\
\hline LP & 4.1 & 3.8 & 3.1 & 3.7 & 4.1 & 5.9 & 0.33 \\
\hline MP & 3.7 & 3.9 & 3.3 & 3.4 & 3.9 & 4.3 & 0.33 \\
\hline \multicolumn{8}{|c|}{ Glucose, $\mathrm{mg} / \mathrm{dl}$} \\
\hline LP & 62.4 & 64.6 & 59.9 & 61.3 & 58.7 & 64.3 & 2.10 \\
\hline MP & 62.2 & 59.0 & 60.9 & 58.3 & 63.2 & 66.8 & 2.07 \\
\hline \multicolumn{8}{|c|}{ NEFA, $\mu \mathrm{Eq} / \mathrm{L}^{6}$} \\
\hline LP & 243.2 & 248.7 & 346.4 & 436.7 & 434.5 & 707.1 & 37.36 \\
\hline MP & 192.3 & 261.9 & 265.7 & 275.7 & 353.5 & 531.7 & 37.36 \\
\hline
\end{tabular}

${ }^{1}$ Day relative to parturition.

${ }^{2}$ Weighted average of the SEM across days prior to parturition.

${ }^{3}$ Day $(P<0.01)$.

${ }^{4} \mathrm{LP}=$ Low protein; $\mathrm{MP}=$ moderate protein.

${ }^{5}$ Day $(P<0.005)$.

${ }^{6}$ Day $(P<0.0001)$.

fiber degradation was probably affected by increasing dietary $\mathrm{CP}$ as RDP.

Plasma urea concentrations were not affected by dietary treatment (Table 4). Plasma urea concentrations decreased as animals approached parturition $(P<0.01$; Table 4). Greenfield et al. (2000) also observed a decrease in plasma urea concentrations as cows approached parturition. Decreased concentrations of plasma urea probably reflect decreased CP intake. Plasma urea concentrations were quite high considering rumen ammonia concentrations were very low. We are unaware of any other study comparing rumen ammonia and plasma urea concentrations in prepartum transition cows.

Plasma NEFA concentrations were not affected by treatment and increased as animals approached parturition $(P<0.0001$; Table 4$)$. VandeHaar et al. (1999) also observed no effect of dietary CP level (12 vs. $16 \%$ $\mathrm{CP}$ ) on plasma NEFA concentration as cows approached parturition. The increase in concentration of NEFA as calving approaches is commonly observed and is probably related to decreased DMI and hormonal changes associated with parturition and lactogenesis. Bertics et al. (1992) decreased the magnitude of NEFA increase by force-feeding cows during the prepartum transition period but could not eliminate it completely.

Glucose concentrations were not affected by treatment or day relative to parturition, but numerically they did initially decrease and then increase as animals reached calving. This pattern has been seen before (Vazquez-Anon et al., 1994; Greenfield et al., 2000). The observed increase in plasma glucose concentrations, im- mediately prepartum, may be related to increased gluconeogenesis, glycogenolysis, or both.

Plasma concentrations of BHBA increased as animals approached parturition $(P<0.005$; Table 4$)$, which agrees with others (Grum et al., 1996; Greenfield et al., 2000). This is probably related to increased NEFA mobilization from adipose and hepatic metabolism to BHBA while DMI is decreasing. There was no effect of dietary CP concentration on plasma BHBA concentrations. Greenfield et al. (2000) observed no difference in BHBA concentrations between cows fed 12 or $16 \%$ dietary CP during the prepartum transition period.

There were several effects of parity on blood metabolites. An interaction of day relative to parturition and parity for NEFA concentration was observed $(P<$ 0.005); heifers had higher concentrations of plasma NEFA as they approached calving (Figure 5). Over all time points, heifers had higher concentrations of plasma NEFA than cows, but the difference was not significant (Table 5). Moore et al. (2000) and VandeHaar et al. (1999) also observed this. We are unable to

Table 5. Effects of parity on blood plasma metabolites.

\begin{tabular}{|c|c|c|c|}
\hline \multirow[b]{2}{*}{ Parameter } & \multicolumn{2}{|c|}{ Parity } & \multirow[b]{2}{*}{ SEM } \\
\hline & Heifer & Cow & \\
\hline NEFA, $\mu \mathrm{Eq} / \mathrm{L}^{1}$ & 384.1 & 291.7 & 37.86 \\
\hline Urea, mg/dl ${ }^{1}$ & 17.7 & 22.2 & 1.47 \\
\hline Glucose, $\mathrm{mg} / \mathrm{dl}^{2}$ & 65.8 & 58.8 & 2.08 \\
\hline BHBA, mg/dl & 3.5 & 4.2 & 0.32 \\
\hline
\end{tabular}

${ }^{1}$ Parity $(P<0.15)$.

${ }^{2}$ Parity $(P<0.05)$. 


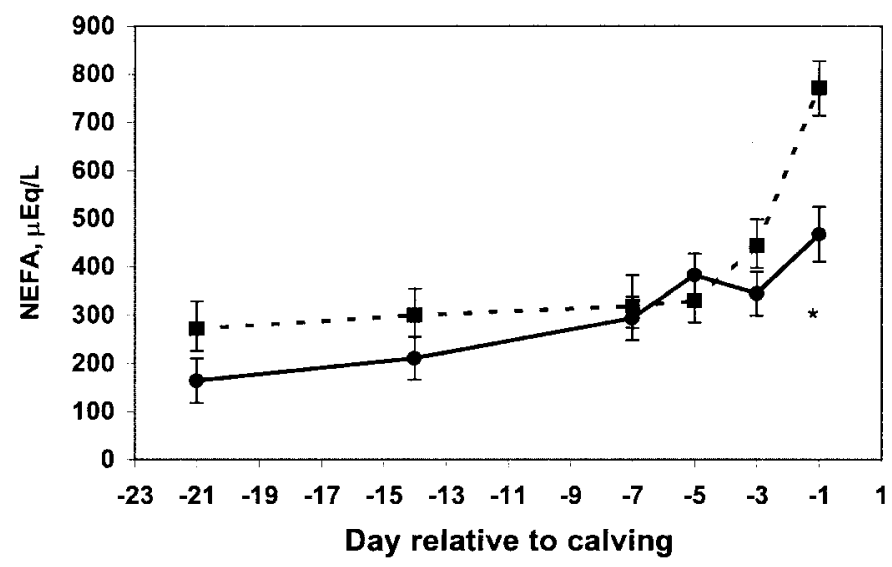

Figure 5. Effect of day relative to calving and parity (heifer $\mathbf{\square}$; cow O) on blood plasma NEFA concentration. Interaction between parity and day relative to calving was significant $(P<0.005) .{ }^{*}=$ Significantly different values within a day $(P<0.05)$.

explain why heifers had higher plasma concentrations of NEFA; perhaps they experience more stress during late gestation. Heifers also had higher concentrations of plasma glucose $(P<0.05$; Table 5$)$, while plasma BHBA concentrations were unaffected by parity. It seems unusual that heifers had higher plasma NEFA concentrations than cows, but they did not have elevated levels of plasma BHBA. This may be related to heifers maintaining higher glucose concentrations due to less demand for glucose by the mammary gland as parturition approaches.

\section{CONCLUSIONS}

Dietary $\mathrm{CP}$ and day relative to parturition had modest effects on rumen VFA concentrations and $\mathrm{pH}$. Often these effects were statistically significant but numerically small. Neutral detergent fiber disappearance from Dacron bags incubated in the rumen was significantly decreased when dietary $\mathrm{CP}$ was $<11 \%$. Changes in NDF digestion due to dietary $\mathrm{CP}$ did not affect blood metabolite concentrations. Additional studies should be conducted to determine if the NRC (2001) recommendation of $12 \%$ dietary CP maximizes fiber degradation in the rumen of prepartum transition cows.

\section{ACKNOWLEDGMENTS}

The authors wish to thank the barn crew at the University of Wisconsin Dairy Cattle Instruction and Research Center, especially Bob Elderbrook for the daily care of the animals.

\section{REFERENCES}

Arieli, A., S. J. Mabjeesh, Z. Shabi, I. Bruckental, Y. Aharoni, S. Zamwel, and H. Targari. 1998. In situ assessment of degradability of organic matter in the rumen of dairy cow. J. Dairy Sci. 81:1985-1990.

Association of Official Analytical Chemists. 1990. Official Methods of Analysis. Vols. 1 and 2. 15th ed. AOAC, Arlington, VA.

Bal, M. A. 1999. Utilization of corn silage by lactating cows. Ph.D. Diss., Univ. Wisconsin, Madison.

Barton, B. A. 1981. Studies on the etiology and prevention of parturient paresis. Ph.D. Thesis, Univ. Wisconsin, Madison.

Bertics, S. J., R. R. Grummer, C. Cadorniga-Valino, and E. E. Stoddard. 1992. Effect of prepartum dry matter intake on liver triglyceride concentration and early lactation. J. Dairy Sci. 75:19141922.

Chaney, A. L., and E. P. Marbach. 1962. Modified reagents for determination of urea and ammonia. Clin. Chem. 8:130-132.

Cherney, D. J. R., J. A. Patterson, and R. P. Lemenager. 1990. Influence of in situ bag rinsing technique on determination of dry matter disappearance. J. Dairy Sci. 73:391-397.

Chew, B. P., R. E. Erb, J. F. Fessler, C. J. Callahan, and P. V. Malven. 1979. Effects of ovariectomy during pregnancy and of prematurely induced parturition on progesterone, estrogens and calving traits. J. Dairy Sci. 62:557-566.

Combs, D. K., and L. D. Satter. 1992. Determination of markers in digesta and feces by direct current plasma emission spectroscopy. J. Dairy Sci. 75:2176-2183.

Crocker, C. L. 1967. Rapid determination of urea nitrogen in serum or plasma without deproteinization. Am. J. Med. Technol. 33:361.

Dixon, R. M. 1999. Effects of addition of urea to a low nitrogen diet on rumen digestion of a range of roughages. Aust. J. Agric. Res. 50:1091-1097.

Doreau, M., A. Delacroix, J. P. Jouany, C. Durier, and B. Remond. 1990. The influence of physiological state and dietary nitrogen supply on digestion in the dairy cow. J. Anim. Sci. 68:3853-3860.

Erwin, E. S., G. J. Marco, E. M. Emery. 1961. Volatile fatty acid analyses of blood and rumen fluid by gas chromatography. J. Dairy Sci. 44:1768-1771.

Grant, R. J., and D. R. Mertens. 1992. Influence of buffer $\mathrm{pH}$ and raw corn starch addition on in vitro fiber digestion kinetics. J. Dairy Sci. 75:2762-2768.

Grant, R. J., and S. J. Weidner. 1992. Digestion kinetics of fiber: influence of in vitro buffer $\mathrm{pH}$ varied within observed physiological range. J. Dairy Sci. 75:1060-1068.

Greenfield, R. B., M. J. Cecava, T. R. Johnson, and S. S. Donkin. 2000. Impact of dietary protein amount and rumen undegradability on intake, prepartum liver triglyceride, plasma metabolites and milk production in transition dairy cattle. J Dairy Sci. 83:703-710.

Grum, D. E., J. K. Drakley, R. S. Younker, D. W. LaCount, and J. J. Veehuizen. 1996. Nutrition during the dry period and hepatic lipid metabolism of periparturient dairy cows. J. Dairy Sci. 79:1850-1864.

Grummer, R. R. 1995. Impact of changes in organic nutrient metabolism on developing feeding strategies to minimize stress during the transition from late pregnancy to early lactation. J. Anim. Sci. 78:2820-2823.

Grummer, R. R., and A. Hayirli. 2001. Feed intake and management of dairy cows during the transition period. 1. Factors affecting dry matter intake of prefresh transition cows. Pages 43-52 in 2001 Intermountain Nutrition Conference. Utah State Univ., Logan, UT.

Hanks, D. R., M. B. Judkins, B. A. McCkarken, D. W. Holcombe, L. J. Krysl, and K. K. Park. 1993. Effects of pregnancy on digesta kinetics and rumen fermentation in beef cows. J. Anim. Sci. $71: 2809-2814$.

Hart, S. P., and H. A. Glimp. 1991. Effect of diet composition and feed intake level on diet digestibility and ruminal metabolism in growing lambs. J. Anim. Sci. 69:1636-1644.

Hayirli, A., R. R. Grummer, E. Nordheim, P. Crump, D. K. Beede, M. J. VandeHaar, and L. H. Kilmer. 1998. A mathematical model for describing dry matter intake of transition cows. J. Dairy Sci. 81(Suppl. 1):296. (Abstr.).

Johnson, M. J., and J. P. Peters. 1993. Technical note: an improved method to quantify nonesterified fatty acids in bovine plasma. J. Anim. Sci. 71:753-756. 
Kunz, P. L., J. W. Blum, I. C. Hart, H. Bickel, and J. Landis. 1985. Effects of different energy intakes before and after calving on food intake, performance, blood hormones, and metabolites in dairy cows. Anim. Prod. 40:219-231.

Mertens, D. R. 1999. Variation in NDF results with modifications of the filter bag method. National Forage Testing Assoc., Technical Session Papers and Committee Rep. to the Board and Membership. Topeka, KS.

Moore, S. J., M. J. VandeHaar, B. K. Sharma, T. E. Pilbeam, D. K. Beede, H. F. Buckholtz, J. S. Leisman, R. L. Horst, and J. P. Golff. 2000. Effects of altering dietary cation-anion difference on calcium and energy metabolism in peripartum cows. J. Dairy Sci. 83:2095-2104.

National Research Council. 2001. Nutrient Requirements of Dairy Cattle. 7th rev. ed. Natl. Acad. Sci., Washinton, DC.

Olsen, K. C., R. C. Chochran, T. J. Jones, E. S. Anzant, E. C. Titgemeyer, and D. E. Johnson. 1999. Effects of ruminal administration of supplemental degradable intake protein and starch on utilization of low-quality warm-season grass hay by beef steers. J. Anim. Sci. 77:1016-1025.

Raabo, E., and T. C. Terkildsen. 1960. On enzymatic determination of blood glucose. Scand. J. Clin. Lab. Invest. 12:402-407.

Robinson, P. H., C. J. Sniffen, and P. J. Van Soest. 1985. Influence of level of feed intake on digestion and bacterial yield in the forestomachs of dairy cattle. Can. J. Anim. Sci. 65:437-444.
Sakata, T., and H. Tamate. 1978. Rumen epithelial cell proliferation accelerated by rapid increase in intraruminal butyrate. J. Dairy Sci. 61:1109-1113.

SAS System for Mixed Models. 1998. SAS Inst., Inc., Cary, NC.

Satter, L. D., and L. L. Slyter. 1974. Effect of ammonia concentration on rumen microbial protein production in vitro. Br. J. Nutr. $32: 199-208$

Sehested, J., J. B. Andersen, O. Aaes, N. B. Kristensen, L. Diernaes, P. D. Møller, and E. Skadhauge. 2000. Feed-induced changes in the transport of butyrate, sodium, and chloride ions across the isolated bovine rumen epithelium. Acta Agric. Scand. 500:47-55.

Stanley, T. A., R. C. Chochran, E. S. Vanzant, D. L. Harmon, and L. R. Coral. 1993. Periparturient changes in intake, ruminal capacity, and digestive characteristics in beef cows consuming alfalfa hay. J. Anim. Sci. 71:788-795.

VandeHaar, M. J., G. Yousif, B. K. Sharma, T. H. Herdt, R. S. Emory, M. S. Allen, and J. S. Liesman. 1999. Effect of energy and protein density of prepartum diets on fat and protein metabolism of dairy cattle in the periparturient period. J. Dairy Sci. 82:1282-1295.

Vazquez-Anon, M., S. J. Bertics, M. Luck, R. R. Grummer, and J. Pinheiro. 1994. Prepartum liver triglyceride and plasma metabolites in dairy cows. J. Dairy Sci. 77:1521-1528.

Williamson, D. H., J. Mellanby, and H. A. Krebs. 1962. Enzymatic determination of $\mathrm{D}(-) \mathrm{B}-\mathrm{Hydroxybutyric}$ acid and acetoacetic acid in blood. Biochem. J. 82:90-98. 